\title{
Microtiter plate assay for phosphate using a europium-tetracycline complex as a sensitive luminescent probe
}

\author{
Axel Duerkop $^{\mathrm{a}, *}$, Matejka Turel ${ }^{\mathrm{a}, \mathrm{b}}$, Aleksandra Lobnik $^{\mathrm{b}}$, Otto S. Wolfbeis ${ }^{\mathrm{a}}$ \\ ${ }^{a}$ University of Regensburg, Institute of Analytical Chemistry, Chemo- and Biosensors, Universitaetsstrasse 31, D-93040 Regensburg, Germany \\ ${ }^{\mathrm{b}}$ University of Maribor, Faculty of Mechanical Engineering, Smetanova 17, SLO-2000 Maribor, Slovenia
}

Received 4 March 2005; received in revised form 22 August 2005; accepted 6 September 2005

Available online 10 October 2005

\begin{abstract}
A new luminescent europium probe is presented for the determination of phosphate $(\mathrm{P})$ in microtiter plate format. The assay is based on the quenching of the luminescence of the europium-tetracycline (EuTc) 1:1 complex by phosphate using a reagent concentration of $20.8 \mu \mathrm{mol} / \mathrm{L}$. The probe is excited at $400 \mathrm{~nm}$ and displays a large Stokes' shift of $210 \mathrm{~nm}$. The emission maximum is located at $616 \mathrm{~nm}$. The system works best at neutral $\mathrm{pH} 7$ and is therefore suitable for phosphate determination in biological and biochemical systems. The linear range of the calibration plot is from $5 \times 10^{-6} \mathrm{~mol} / \mathrm{L}$ to $7.5 \times 10^{-4} \mathrm{~mol} / \mathrm{L}$ of phosphate, and the limit of detection is $3 \mu \mathrm{mol} / \mathrm{L}$.
\end{abstract}

(C) 2005 Elsevier B.V. All rights reserved.

Keywords: Phosphate; Microplate assay; Luminescence; Lanthanide

\section{Introduction}

Phosphate is an essential nutrient and an important substance in metabolism of humans, animals and plants. Therefore, methods were developed for its determination in fertilizers, plants, crops $[1,2]$, natural waters $[3,4]$ and other environmental samples [5]. Phosphate, also, is an important parameter in clinical chemistry [6] and in industry in boiler feed-water to prevent scaling [7].

The broad field of applications is reflected by a huge variety of methods for phosphate determination. Among them, the formation of heteropoly acid complexes between orthophosphates and molybdate is frequently used to obtain a colored species, which is optically easy to determine. Analysis can be performed spectrophotometrically either directly with the yellow heteropoly acid complex (in the UV region) [8] or after reduction to phosphomolybdenum blue with various reducing reagents [9-11]. The sensitivity of these methods depends on acidity, temperature and the reducing agent. However, the acidic pH (between 0.3 and 3) needed in the phosphomolybdenum blue method prevents its applicability to

\footnotetext{
* Corresponding author. Tel.: +49 941943 4053; fax: +49 9419434064.

E-mail address: axel.duerkop@ chemie.uni-regensburg.de (A. Duerkop).
}

bioanalysis (where enzymes, for example, require near-neutral $\mathrm{pH})$.

Other optical methods for phosphate detection include light scattering techniques (using malachite green or rhodamine B) [12] in a combination with flow injection analysis and fluorescence quenching of rhodamine $6 \mathrm{G}$ [13] with molybdophosphate. Thiamine was used for fluorometric determination of phosphate in HPLC at a comparatively short emission wavelength of $437 \mathrm{~nm}$ [14]. The procedure is laborious, because careful $\mathrm{pH}$ adjustment is needed throughout the analytical process and the assay is prone to interference by oxidation of background [15]. The method using the fluorescent $\mathrm{Al}^{3+}$-morin complex [16] works at acidic conditions and suffers from a long incubation time of $45 \mathrm{~min}$, while the spectrophotometric determination with Alizarin Red sulfonate [17] at pH 6.6 works in the millimolar concentration range, only. Recently, a spectrophotometric $\mathrm{C}_{3 v}$ symmetric synthetic receptor [18] for tetrahedral oxyanions was employed in an indicator-displacement assay. It works best at $\mathrm{pH}$ 7.4 in the biological range.

Electrochemical methods mostly use ion selective electrodes for phosphate detection. The response time of some potentiometric schemes [19-21] is within minutes at $\mathrm{pH}$ around 9.7. Amperometric schemes [22] have also been presented. Here, the response times are fast, too $(1 \mathrm{~min})$, but again a fairly alkaline $\mathrm{pH}$ has to be used. 
Finally, a coupled enzyme system, which incorporates three enzymes together with the formation of resorufin from Amplex Red was shown for the detection of low concentrations (50 nM) of phosphate at $\mathrm{pH}$ 7.4. The drawbacks of this method are high costs for the reagents (three enzymes and the Amplex Red dye), an incubation time of $0.5 \mathrm{~h}$, and interference of detergents like 3(cyclohexylamino)-propanesulfonic acid (CAPS) or SDS [23]. However, this assay is very popular because it works at $\mathrm{pH} 7$.

Luminescence detection along with microtiter plate formats provides a high throughput technology for clinical assays with sensitive determination of low analyte concentrations [24-26]. The unique spectral properties of lanthanide cations (long luminescence lifetimes, sharp emission bands, a large energy gap between the absorption and emission bands of the complexes) make them ideally suited as specific reporters in such applications.

We recently introduced the EuTc system for the determination of hydrogen peroxide [27-29]. Here, a 3:1 stoichiometry was employed for sensitive determination of hydrogen peroxide in microtiter plate format, in sensor membranes and in various matrices. The method showed some interference due to phosphate. From this finding, we deduced that a detection scheme for phosphate could be established. Upon changing the stoichiometry between $\mathrm{Eu}^{3+}$ and Tc and optimizing further parameters like $\mathrm{pH}$, an assay for the luminescent determination of phosphate was developed and is presented here. It is simple, fast, and can be performed in aqueous buffer at neutral $\mathrm{pH}$ and is therefore suitable for phosphate determination in biological and biochemical systems. We have optimized stoichiometry, incubation time and $\mathrm{pH}$ and report on the effect of interferences. The assay was validated by using different natural water samples as a matrix that was spiked with different concentrations of phosphate.

\section{Experimental}

\subsection{Chemicals and buffers}

All chemicals used were of analytical grade. Tetracycline hydrochloride was purchased from Serva (Heidelberg, Germany), europium trichloride hexahydrate $\left(\mathrm{EuCl}_{3} \cdot 6 \mathrm{H}_{2} \mathrm{O}\right)$ from Alfa (Karlsruhe, Germany), 3-morpholino-propanesulfonic acid (MOPS) from ABCR (Karlsruhe, Germany) and sodium dihydrogenphosphate monohydrate $\left(\mathrm{NaH}_{2} \mathrm{PO}_{4} \cdot \mathrm{H}_{2} \mathrm{O}\right)$ from Merck (Darmstadt, Germany). Water was doubly distilled.

All solutions were prepared in $13 \mathrm{mmol} / \mathrm{L}$ MOPS buffer. This buffer was obtained by dissolving $5.92 \mathrm{~g}$ of 3-morpholinopropanesulfonic acid in $1900 \mathrm{~mL}$ of doubly distilled water. Before being filled up to $2000 \mathrm{~mL}$, the solution was adjusted to $\mathrm{pH} 7$ using $70 \%$ perchloric acid. Desired concentrations of phosphate were obtained by dissolving the $\mathrm{NaH}_{2} \mathrm{PO}_{4} \cdot \mathrm{H}_{2} \mathrm{O}$ salt in MOPS buffer.

\subsection{EuTc reagent}

The EuTc reagent solution was obtained by dissolving $4.9 \mathrm{mg}$ of tetracycline hydrochloride and $3.8 \mathrm{mg}$ of $\mathrm{EuCl}_{3} \cdot 6 \mathrm{H}_{2} \mathrm{O}$ in $250 \mathrm{~mL}$ of MOPS buffer to give a concentration of $41.5 \mu \mathrm{mol} / \mathrm{L}$.
The EuTc stock solution was allowed to stay at $4{ }^{\circ} \mathrm{C}$ in the dark overnight before use. The EuTc solution is stable for at least 1 month at $4{ }^{\circ} \mathrm{C}$.

\subsection{Instrumentation}

Luminescence spectra were acquired on an Aminco Bowman AB2 luminescence spectrometer (from SLM Spectronic Unicam, Rochester, New York, USA). Luminescence was excited at $400 \mathrm{~nm}$ and emission was collected at $616 \mathrm{~nm}$. Bandpasses were set to $4 \mathrm{~nm}$ for both, the excitation and emission slit. A PMT voltage of $905 \mathrm{~V}$ was applied. Measurements were carried out after an incubation time of $20 \mathrm{~min}$ at $30^{\circ} \mathrm{C}$.

Luminescence measurements in microtiter plates (MTP) were performed using 96-well flat bottom black microplates (from Greiner Bio-One GmbH, Frickenhausen, Germany) on a Genios Plus microplate reader (from Tecan, Grödig, Austria). Unless otherwise described, the instrumental parameters of the MTP reader were as follows: excitation and emission wavelengths at 405/612 nm, gain: $131 \mathrm{~V}, 10$ flashes per well, lagtime $0 \mu \mathrm{s}$, integration times $40 \mu \mathrm{s}$ (or lagtime $60 \mu \mathrm{s}$ and integration time $100 \mu \mathrm{s}$ for better sensitivity between 3 and $10 \mu \mathrm{mol} / \mathrm{L}$ of phosphate, respectively); time gap between move and flash: $200 \mathrm{~ms}$. The plates were thermostatted to $30^{\circ} \mathrm{C}$ and luminescence was read after $1200 \mathrm{~s}$ of shaking.

\subsection{Preparation of solutions}

Solutions for the acquisition of the emission spectra were prepared as follows: $2.5 \mathrm{~mL}$ of the solution in the cuvettes had the concentration of EuTc $20.8 \mu \mathrm{mol} / \mathrm{L}$ and contained final concentrations of phosphate between 25 and $500 \mu \mathrm{mol} / \mathrm{L}$. The samples were allowed to thermostat at $30{ }^{\circ} \mathrm{C}$ for $20 \mathrm{~min}$ before measurement.

Solutions for the determination of the $\mathrm{pH}$ effect were prepared as follows: $250 \mu \mathrm{L}$ of an $20.8 \mu \mathrm{mol} / \mathrm{L} \mathrm{EuTc}$ solution of different $\mathrm{pH}$ (from 5.5 to 8.2) were pipetted into a 96-well microplate. Two rows of the wells contained solutions of the same $\mathrm{pH}$. To each second row were added $5 \mu \mathrm{L}$ of a $250 \mu \mathrm{mol} / \mathrm{L}$ phosphate solution. Here, a PMT voltage of $120 \mathrm{~V}$ was used.

Solutions for the calibration plot in the concentration range of $0.2-1000 \mu \mathrm{mol} / \mathrm{L}$ of phosphate were prepared in columns of eight replicates for each concentration of phosphate in 96-well microplates. After the first $50 \mu \mathrm{L}$ of MOPS buffer solution in each well, $100 \mu \mathrm{L}$ of phosphate solutions of different concentration (from 0.5 to $2500 \mu \mathrm{mol} / \mathrm{L}$ ) were added. Finally, $125 \mu \mathrm{L}$ of EuTc reagent solution was added.

Different concentrations of conceivable interferents were additionally prepared to be checked for their effect on the average luminescence intensity of EuTc in the presence of $25 \mu \mathrm{mol} / \mathrm{L}$ of phosphate. Each concentration of interferent was tested in eight replicates. The concentrations of the interferent were varied in the range between 0.01 and $1000 \mu \mathrm{mol} / \mathrm{L}$.

For the validation test, three different natural water samples were tested in microtiter plates. To $50 \mu \mathrm{L}$ of each water sample was added $75 \mu \mathrm{L}$ of phosphate solution of different concentrations and $125 \mu \mathrm{L}$ of EuTc to obtain final concentrations of 
phosphate between 10 and $375 \mu \mathrm{mol} / \mathrm{L}$. The samples were analyzed on the basis of the calibration plot established, and its slope.

\section{Results}

\subsection{Spectral properties of EuTc in the presence of phosphate}

The EuTc probe shows an excitation maximum at $400 \mathrm{~nm}$, and the emission maximum is at $616 \mathrm{~nm}$. The line-like emission peak is typical for a lanthanide emission. The probe displays a $\sim 210 \mathrm{~nm}$ Stokes' shift. On addition of phosphate in MOPS buffer of $\mathrm{pH} \mathrm{7,} \mathrm{the} \mathrm{luminescence} \mathrm{intensity} \mathrm{of} \mathrm{EuTc}$ decreases. This is shown in Fig. 1 for the concentration range from 25 to $500 \mu \mathrm{mol} / \mathrm{L}$ of phosphate. We assume that phosphate anions coordinate to EuTc due to electrostatic interactions with the metal center and contribute to lower the energy transfer from tetracycline to $\mathrm{Eu}^{3+}$, thus quenching its emission intensity.

\subsection{Effect of $p H$}

Previous studies of the effect of $\mathrm{pH}$ on the luminescence intensity of the EuTc complex in various molar ratios had revealed [30] that its intensity is highly $\mathrm{pH}$ dependent. If the stoichiometry of Eu:Tc is 3:1, the emission intensity of EuTc is strongest in the $\mathrm{pH}$ range of 6.6-7.2 [27]. Fig. 2 shows the $\mathrm{pH}$ dependence of the emission intensity of EuTc in a 1:1 molar ratio in absence and presence of phosphate. The error bars represent standard deviations from eight replicate samples. Here, the luminescence intensity is increasing from lower (5.5) to higher $\mathrm{pH}$ (8.2) in the absence of phosphate (solid squares). After the addition of phosphate $(5 \mu \mathrm{mol} / \mathrm{L})$, the overall signal decreases. On going from $\mathrm{pH} 6.5$ to 8.2 , the luminescence decreases by between 33 and $38 \%$. Since the signal decrease at $\mathrm{pH} 7$ is not distinctly smaller than at more alkaline $\mathrm{pH}$, we chose $\mathrm{pH} 7.0$ for the following experiments in order to make the assay useful for physiological studies.

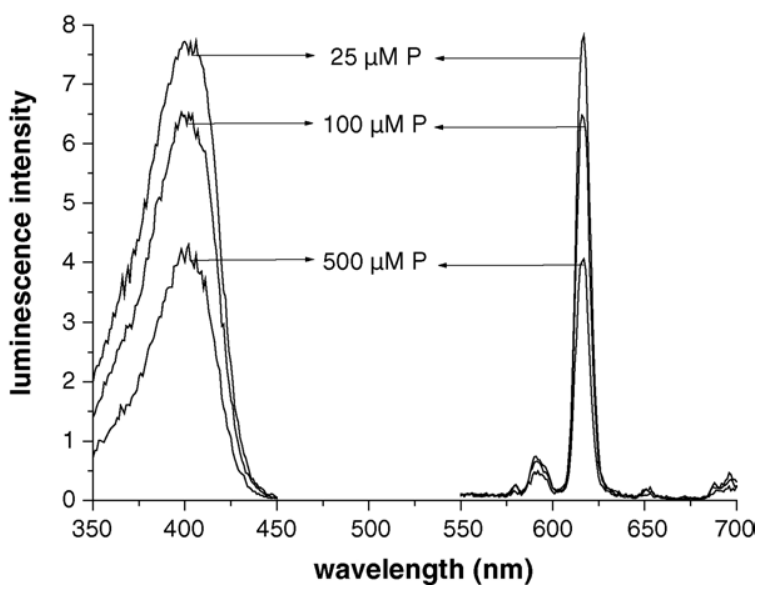

Fig. 1. Excitation and emission spectra of EuTc in presence of various concentrations of phosphate $(\mathrm{P})$ in MOPS buffer of $\mathrm{pH} 7\left(\lambda_{\mathrm{exc}} 400 \mathrm{~nm}, \lambda_{\mathrm{em}} 616 \mathrm{~nm}\right)$.

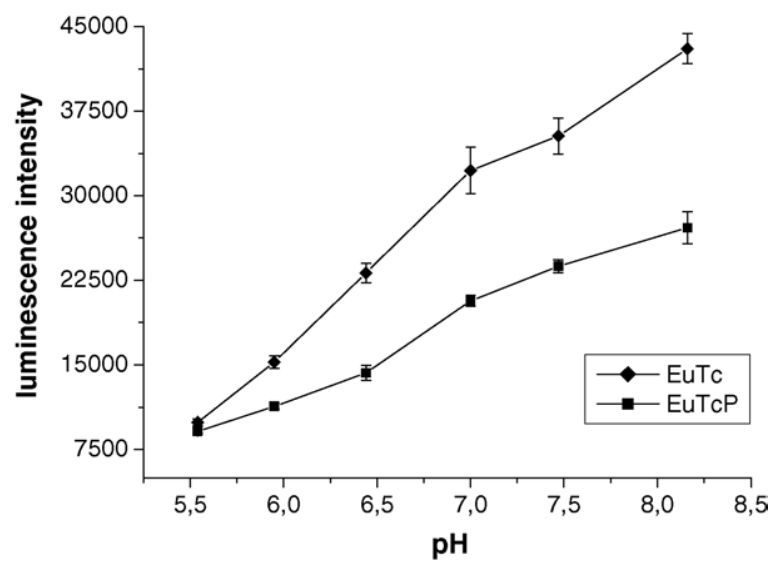

Fig. 2. Effect of $\mathrm{pH}$ on the luminescence intensity of EuTc in the absence and presence of phosphate $(5 \mu \mathrm{mol} / \mathrm{L})$.

\subsection{Time dependence of complexation between EuTc and phosphate}

Fig. 3 shows the time-dependent decrease of the luminescence intensity of EuTc upon addition of $350 \mu \mathrm{mol} / \mathrm{L}$ of phosphate at $\mathrm{pH} 7$ in MOPS buffer. The luminescence intensity of the probe in absence of phosphate is stable over time $(30 \mathrm{~min})$. Following addition of phosphate, the change of the luminescence signal of EuTc was followed over $1800 \mathrm{~s}$. The signal decreases for $1200 \mathrm{~s}$ and lowers very modestly using longer incubation times. After a $20 \mathrm{~min}$ incubation time, the relative signal change is smaller by only $10 \%$ compared to $1800 \mathrm{~s}$. Since this difference is small, we chose an incubation time of $1200 \mathrm{~s}(20 \mathrm{~min})$ for the phosphate assay. A $20 \mathrm{~min}$ incubation time turned out to be optimal, even for lower concentrations of phosphate. The reliability of this incubation time was confirmed by minimized standard deviations at $1200 \mathrm{~s}$ incubation time in the subsequent experiments in microtiter plates.

\subsection{Effect of stoichiometry}

The stoichiometry of the EuTc complex has a large effect on its luminescence intensity. According to our measurements and

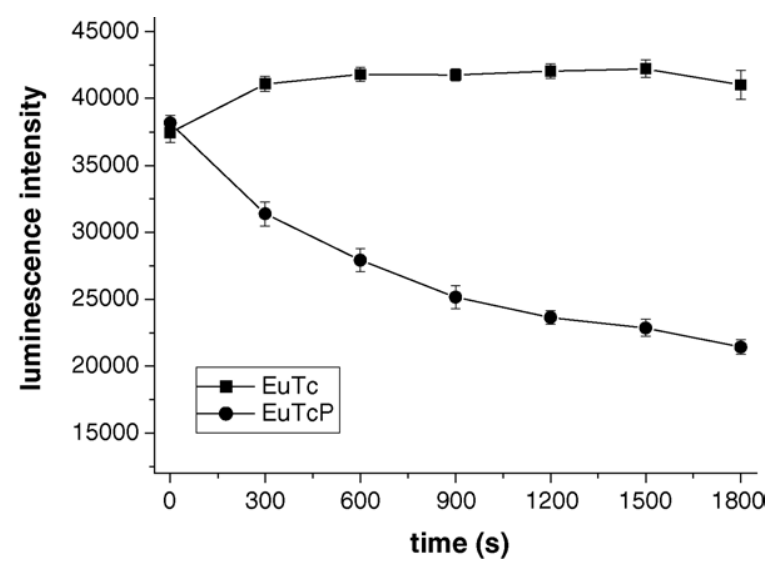

Fig. 3. Time-dependent changes in luminescence intensity of EuTc at $616 \mathrm{~nm}$ $\left(\lambda_{\text {exc }}=400 \mathrm{~nm}\right)$ in MOPS buffer of $\mathrm{pH} 7$ in the absence (top) and in the presence (lower plot) of phosphate $(350 \mu \mathrm{mol} / \mathrm{L})$. 
previous studies [27-29], an excess of $\mathrm{Eu}^{3+}$ over Tc results in a weak enhancement of the luminescence intensity of the EuTc in the region of neutral $\mathrm{pH}$ upon addition of phosphate. At a molar ratio $\mathrm{Eu}: \mathrm{Tc}=1: 1$, however, the addition of phosphate results in a pronounced decrease of EuTc luminescence intensity. On the other hand, no significant cross-sensitivity towards $<100 \mu \mathrm{M}$ concentrations of hydrogen peroxide is found under these conditions (see interference study). Therefore, a stoichiometry of EuTc 1:1 was used in all experiments.

\subsection{Calibration plot}

The assay shows high accuracy for the determination of phosphate within the linear range of the calibration plots. For better comparability of the two different detection methods, we show $F / F_{0}$ (normalized luminescence intensity against luminescence signal in absence of phosphate) in Fig. 4. In semilogarithmic representation, the plot with $0 \mu$ s lagtime detection can be described by an equation of the type $y=A+B \log \left(c_{\text {phosphate }} \times 10^{6}\right)$, with $A=1.033 \pm 0.018$ and $B=-0.224 \pm 0.007$, for which an $r^{2}$ of 0.993 is found (Fig. 4, squares). The analytically useful range spans more than two decades (from 5 to $750 \mu \mathrm{mol} / \mathrm{L}$ of phosphate). The limit of detection is $5 \mu \mathrm{mol} / \mathrm{L}$ of phosphate. The shape of the calibration plot extends linearly over a relatively wide range $(5-750 \mu \mathrm{mol} / \mathrm{L})$. This is interpreted by an overlap of two plots, one for primary phosphate (the predominant species at $\mathrm{pH}<7.3$ ) and secondary phosphate (the predominant species at $\mathrm{pH}>7.3$ ). At $\mathrm{pH} 7.0$, both species are present in substantial fraction. In fact, distinctly different calibration plots (not shown) are found for determinations performed at $\mathrm{pH} 6$ and 8, respectively. Since, however, the effects described before are largest at $\mathrm{pH} 7.0$, we think that this is the most appropriate $\mathrm{pH}$ for determination of phosphate.

Upon using a lagtime of $60 \mu \mathrm{s}$ and an integration time of $100 \mu \mathrm{s}$, both the LOD and the sensitivity of the method can be improved. This is reflected well by the much steeper slope of the calibration plot (Fig. 4, circles). In semilogarithmic representation, the plot with $60 \mu \mathrm{s}$ lagtime and $100 \mu \mathrm{s}$ integra-

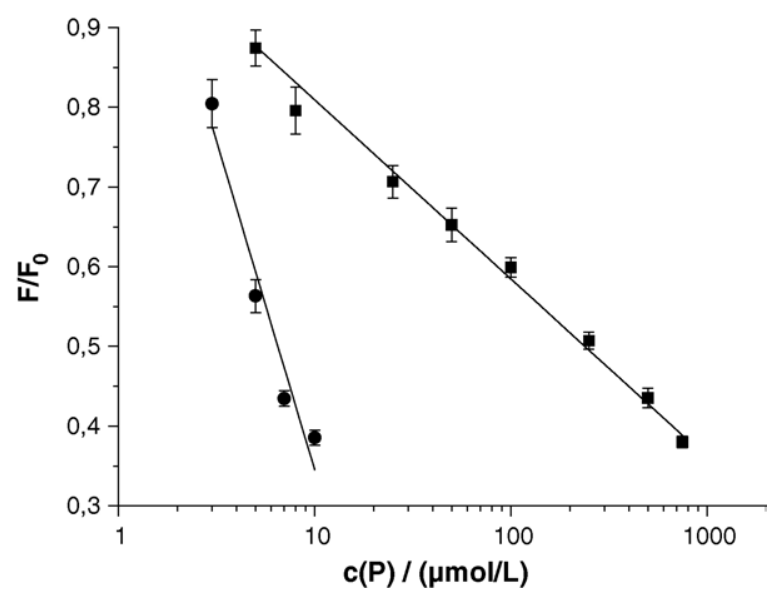

Fig. 4. Calibration plots for the phosphate assay with $0 \mu$ s lagtime and $40 \mu \mathrm{s}$ integration time (squares) and $60 \mu \mathrm{s}$ lagtime and $100 \mu \mathrm{s}$ integration time (circles). tion time detection can be described by an equation of the type $y=\mathrm{A}+B \log \left(c_{\text {phosphate }} \times 10^{6}\right)$, with $A=0.955 \pm 0.081$ and $B=-0.586 \pm 0.091$, for which an $r^{2}$ of 0.954 is found. The analytically useful range is between 3 and $10 \mu \mathrm{mol} / \mathrm{L}$ of phosphate. The limit of detection is $3 \mu \mathrm{mol} / \mathrm{L}$ of phosphate.

\subsection{Interferences}

The luminescence of the EuTc 1:1 complex is not interfered by $\mathrm{K}^{+}, \mathrm{Na}^{+}$and $\mathrm{Ca}^{2+}$ in concentrations up to $1 \mathrm{mmol} / \mathrm{L}$, while $\mathrm{Mg}^{2+}$ and $\mathrm{Al}^{3+}$ have a weak effect (Table 1). $\mathrm{Mg}^{2+}$ increases the luminescence signal of EuTc at concentrations $>20 \mu \mathrm{mol} / \mathrm{L}$, whereas $\mathrm{Al}^{3+}$ increases the luminescence signal when present in concentrations $>100 \mu \mathrm{mol} / \mathrm{L}$. $\mathrm{Fe}^{3+}$ is tolerated up to $15 \mu \mathrm{mol} / \mathrm{L}$ and $\mathrm{Tb}^{3+}$ (as the only other strongly fluorescent lanthanide) up to $33 \mu \mathrm{mol} / \mathrm{L}$.

Ligands containing oxygen with negative charge and anions have to be considered in the interference study because they may coordinate (like phosphate) the $\mathrm{Eu}^{3+}$ ion and affect its emission. However, sulfate, nitrate, acetate and carbonate do not interfere in concentrations up to $1 \mathrm{mmol} / \mathrm{L}$, silicate can be present up to $500 \mu \mathrm{mol} / \mathrm{L}$. The $\mathrm{AsO}_{4}{ }^{3-}$ ion is tolerated up to $100 \mu \mathrm{mol} / \mathrm{L}$ and $\mathrm{AsO}_{3}{ }^{3-}$ up to $90 \mu \mathrm{mol} / \mathrm{L}$. Oxalic acid weakly interferes if present at concentrations $>250 \mu \mathrm{mol} / \mathrm{L}$. Tartaric acid increases the signal at above $160 \mu \mathrm{mol} / \mathrm{L}$, while citric acid increases the luminescence significantly at above $0.8 \mu \mathrm{mol} / \mathrm{L}$. Ammonium ion does not interfere up to $1 \mathrm{mmol} / \mathrm{L}$. Among the halides tested, $\mathrm{F}^{-}$ increases the luminescence at concentrations $>100 \mu \mathrm{mol} / \mathrm{L}$, and $\mathrm{Cu}^{2+}$ is found to act as a quencher if present in concentrations $>0.8 \mu \mathrm{mol} / \mathrm{L}$.

Table 1

Concentrations of interferences tolerated in the presence of phosphate $(25 \mu \mathrm{mol} / \mathrm{L})$

\begin{tabular}{lc}
\hline Interferent & Concentration $(\mu \mathrm{mol} / \mathrm{L})$ \\
\hline Citric acid & 0.8 \\
$\mathrm{Cu}^{2+}$ & 0.8 \\
Tartaric acid & 160 \\
$\mathrm{H}_{2} \mathrm{O}_{2}$ & 100 \\
$\mathrm{~K}^{+}$ & 1000 \\
$\mathrm{~Tb}^{3+}$ & 33 \\
$\mathrm{Fe}^{3+}$ & 15 \\
$\mathrm{Ca}^{2+}$ & 1000 \\
$\mathrm{Mg}^{2+}$ & 20 \\
$\mathrm{Al}^{3+}$ & 100 \\
$\mathrm{Na}^{+}$ & 1000 \\
$\mathrm{~F}^{-}$ & 100 \\
$\mathrm{Cl}^{-}$ & 1000 \\
$\mathrm{Br}^{-}$ & 1000 \\
$\mathrm{I}^{-}$ & 1000 \\
$\mathrm{NO}_{3}{ }^{-}$ & 1000 \\
$\mathrm{SO}_{4}{ }^{2-}$ & 1000 \\
$\mathrm{NH}_{4}^{+}$ & 1000 \\
$\mathrm{CH}_{3} \mathrm{COO}^{-}$ & 1000 \\
$\mathrm{CO}_{3}{ }^{2-}$ & 1000 \\
$\mathrm{AsO}_{4}{ }^{3-}$ & 100 \\
$\mathrm{AsO}_{3}{ }^{3-}$ & 90 \\
$\mathrm{SiO}_{3}{ }^{-}$ & 500 \\
$\mathrm{C}_{2} \mathrm{O}_{4}{ }^{2-}$ & 245 \\
\hline &
\end{tabular}


Table 2

Slopes of calibration plots and recovery rates of phosphate $(\mathrm{P})$ in different natural water samples

\begin{tabular}{|c|c|c|c|c|c|c|}
\hline Water sample & Slope & $\begin{array}{l}\text { Recovery of } \\
10.5 \mathrm{mM} \mathrm{P}(\%)\end{array}$ & $\begin{array}{l}\text { Recovery of } \\
25.5 \mathrm{mM} \mathrm{P}(\%)\end{array}$ & $\begin{array}{l}\text { Recovery of } \\
52.5 \mathrm{mM} \mathrm{P}(\%)\end{array}$ & $\begin{array}{l}\text { Recovery of } \\
120 \mathrm{mM} \mathrm{P}(\%)\end{array}$ & $\begin{array}{l}\text { Recovery of } \\
375 \mathrm{mM} P(\%)\end{array}$ \\
\hline S1 & $-10371.9 \pm 853$ & 101.3 & 97.7 & 102.6 & 96.1 & 102.5 \\
\hline $\mathrm{S} 2$ & $-7177.4 \pm 1235$ & 103.6 & 96.1 & 100.0 & 96.3 & 104.1 \\
\hline $\mathrm{S} 3$ & $-4848.4 \pm 1150$ & 103.6 & 97.3 & 97.8 & 98.1 & 103.3 \\
\hline
\end{tabular}

Sources: S1, Regensburg university lake; S2, Danube river at Regensburg; S3, Laaber river.

It is important to note that the effect of hydrogen peroxide is comparatively low. Although EuTc in 3:1 stoichiometry was used in previous studies to determine $\mathrm{H}_{2} \mathrm{O}_{2}$ in water samples or in enzymatic reactions in which hydrogen peroxide was involved as a substrate [27] or as a product [28,29], $\mathrm{H}_{2} \mathrm{O}_{2}$ does not interfere in concentrations up to $100 \mu \mathrm{mol} / \mathrm{L}$, if the stoichiometry of Eu:Tc is $1: 1$.

The influence of humic acids (HAs) on phosphate determination is difficult to estimate for because of the polydispersity of complexing carboxy groups and the large range of molecular weight $\left(10^{2}-10^{5} \mathrm{~g} / \mathrm{mol}\right)$ of HAs. The $\log k$ of the formation constants of EuTc at pH 7 is about 10 [30] whereas $\log k$ of $\mathrm{Eu}(\mathrm{III})$ with Aldrich humic acid as a model substance varies between -1.75 and -5.25 [31]. From those values, the ability of HAs to complex europium is small. However, a model humic acid was used in [31] and the formation constants depend on $\mathrm{pH}, c_{\mathrm{Eu}^{3+}}, c_{\mathrm{HA}}$, mole fraction of the HA chosen and polydispersity of complexing groups. Consequently, the $\log k$ of the formation constants may vary significantly between different samples containing HAs. Therefore, we recommend setting up a calibration plot with spiking (see Section 3.7.) for samples containing HAs to estimate their possible effect on phosphate determination.

\subsection{Application to spiked water samples}

The assay was tested for its validation using three different natural water samples (Table 2). First, three water samples (S1, S2 and S3) were spiked with different concentrations of phosphate $(10.5,25.5,52.5,120$ and $375 \mu \mathrm{mol} / \mathrm{L})$. After the luminescence intensity was measured, the slopes of the resulting calibration plots were compared to the slope of the standard phosphate assay $(-10350 \pm 350)$. The value of the slope is different from the one in Fig. 4 because here luminescence intensity $(F)$ was taken as a function of $\log \left(c_{\text {phosphate }} \times 10^{6}\right)$ whereas in Fig. $4\left(F / F_{0}\right)$ was a function of $\log \left(c_{\text {phosphate }} \times 10^{6}\right)$. The lake water $S 1$ gave the most similar slope $(-10370 \pm 850)$. This corresponds to a deviation of only $2.6 \%$ from the phosphate assay slope. The recovery rates of the lake water samples (Table 2) are within the tolerable range. Therefore, the assay is suitable for phosphate determination in lake water samples. The two river water systems (S2 and S3) gave different slopes $(-7180 \pm 1240$ and $-4850 \pm 1150)$. This corresponds to a reduced sensitivity of the assay. At present, we suppose that there are some contents present in water samples, which increase the luminescence background resulting in a decreased dynamic range of the determination as shown by the reduced slope.
The assay also was performed in time-resolved mode. The application of different lagtimes $(10,20$ and $40 \mu \mathrm{s})$ had no significant effect on the assay performance when different phosphate concentrations were determined in natural water samples. The advantage of a lower luminescence background was compensated for larger standard deviations of a series of replicate measurements.

\section{Discussion}

EuTc represents a promising new fluorescent probe that displays specific advantages over established procedures for phosphate determination. Table 3 gives figures of merit of common methods for phosphate determination, in particular analytical ranges, LODs, and specific features.

The luminescence properties of EuTc include a comparatively longwave excitation, a Stokes' shift of >200 nm and a sharp emission band at $616 \mathrm{~nm}$. This makes it most useful for determination of phosphate in biological material where fluorescence background in the UV and near visible usually is strong. None of the fluorometric methods [13,14,16,23] offers such a longwave detection. Except from the two molybdenumblue methods $[9,10]$ the spectrophotometric determinations use shorter detection wavelengths. Here, significant background interference due to scatter or other biomaterial is likely to occur.

The incubation time is in the same time range as most of the other methods, except for the methods based on thin film electrodes [19-21] and on the reduced molybdophosphate complex [10] which show a remarkably faster response. The method with morin [16] requires incubation times, which are more than twofold longer than in case of EuTc. The same is true for the assay using the enzymatic assay with Amplex Red [23], where time-consuming pipetting steps (five reagents) are required, followed by a 30 min incubation.

Analytical methods requiring highly acidic or alkaline $\mathrm{pH}$ are hardly applicable to bioanalysis. EuTc works best at a neutral pH 7, which is often a necessity if samples contain enzymes, proteins or other biomaterials. The molybdenum reagents, for example, require highly acidic media $(\mathrm{pH} 0.9-2.5)$ [7-10]. This is also true for the methods using malachite green [12], rhodamine $[12,13]$ or thiamine [14]. The determination using thiamine is even more complicated, because careful and long lasting $\mathrm{pH}$ adjustment procedures are needed (starting with $\mathrm{pH} 2$, ending with $\mathrm{pH}$ 8) [15]. The determination of phosphate using the fluorescent $\mathrm{Al}^{3+}$-morin complex works best at ( $\left.\mathrm{pH} 3.53\right)$, [16], whereas the electrochemical thin film sensor methods use basic reaction conditions ( $\mathrm{pH}$ 9.7) [19-21]. The spectrophotometric 
Table 3

Figures of merit of methods for (optical) determination of phosphate

\begin{tabular}{|c|c|c|c|c|c|}
\hline References & Method & Reagent & Analytical range $(\mathrm{mol} / \mathrm{L})$ & $\mathrm{LOD}(\mathrm{mol} / \mathrm{L})$ & Remarks \\
\hline [8] & Spectrophotometry at $370 \mathrm{~nm}$ & Molybdenum yellow & $2.6 \times 10^{-6}-3.1 \times 10^{-5}$ & $2.6 \times 10^{-6}$ & $\begin{array}{l}\text { Surfactant (CTAB)-based separation technique, high acidity }(0.27 \mathrm{M} \\
\text { sulfuric acid solution); } 5-10 \text { min incubation time at } 30-40^{\circ} \mathrm{C}\end{array}$ \\
\hline [9] & Spectrophotometry at $865 \mathrm{~nm}$ & Molybdenum blue & $5.3 \times 10^{-6}-7.4 \times 10^{-4}$ & $5.3 \times 10^{-6}$ & $\begin{array}{l}\text { Application to flow injection analysis (FIA); } 2 \text { min incubation time; } \mathrm{pH} \\
0.9 \text { and } 2.5\end{array}$ \\
\hline [10] & Spectrophotometry at $880 \mathrm{~nm}$ & Molybdenum blue & $6 \times 10^{-8}-3 \times 10^{-6}$ & n.d. & $\begin{array}{l}\text { In aqueous-organic solution (formation of the reduced } \\
12 \text {-molybdo-phosphate complex); } \mathrm{pH} 0.36-1.06 ; 0.8-1.5 \mathrm{~min} \\
\text { incubation time at RT }\end{array}$ \\
\hline [17] & Spectrophotometry at $478 \mathrm{~nm}$ & Alizarin Red sulfonate & $3.2 \times 10^{-7}-6.3 \times 10^{-5}$ & $3.2 \times 10^{-7}$ & $\mathrm{pH} 6.6$ \\
\hline [12] & Light scattering at $460 \mathrm{~nm}$ & Molybdenum + malachite green & $2 \times 10^{-7}-1 \times 10^{-6}$ & $6 \times 10^{-8}$ & $\begin{array}{l}\text { Application to flow injection (FIA); ion associate aggregates with MG; } \\
\text { high acidity ( } 0.8 \mathrm{M} \text { sulfuric acid); } 3-10 \mathrm{~min} \text { incubation time }\end{array}$ \\
\hline [12] & Light scattering at 460 and $580 \mathrm{~nm}$ & Molybdenum + rhodamine B & $2 \times 10^{-7}-1 \times 10^{-6}$ & $6 \times 10^{-8}$ & $\begin{array}{l}\text { Application to flow injection (FIA); ion associate aggregates with RB; } \\
\text { high acidity ( } 0.8 \mathrm{M} \text { sulfuric acid); } 3-10 \text { min incubation time }\end{array}$ \\
\hline [13] & Fluorescence at $550 \mathrm{~nm}$ & Molybdenum + rhodamine $6 \mathrm{G}$ & $\leq 1.1 \times 10^{-6}$ & $2 \times 10^{-8}$ & $\begin{array}{l}\text { Fluorescence quenching of R6G by molybdophosphate; } 200 \mathrm{~nm} \\
\text { Stokes'shift }\end{array}$ \\
\hline [14] & Fluorescence at $437 \mathrm{~nm}$ & Thiamine & $3.2 \times 10^{-7}-3.2 \times 10^{-6}$ & & $\begin{array}{l}\text { Application to HPLC; } 65 \mathrm{~nm} \text { Stokes' shift; high acidity; } 5 \text { min retention } \\
\text { time }\end{array}$ \\
\hline [16] & Fluorescence at $510 \mathrm{~nm}$ & Al-morin & $5.3 \times 10^{-7}-1.1 \times 10^{-6}$ & & $\begin{array}{l}\text { Fluorescence quenching of Al-morin by phosphate; } \mathrm{pH} 3.53 ; 45 \mathrm{~min} \\
\text { incubation time }\end{array}$ \\
\hline [23] & Fluorescence at $590 \mathrm{~nm}$ & Enzymatic system + Amplex Red & $5 \times 10^{-8}-5 \times 10^{-6}$ & $5 \times 10^{-8}$ & $\begin{array}{l}35 \mathrm{~nm} \text { Stokes' shift, microtiter plate assay possible, three-coupled } \\
\text { enzymatic reactions, } \mathrm{pH} 7.4,5 \text { reagents required, } 30 \mathrm{~min} \text { incubation }\end{array}$ \\
\hline [19] & Transmittance at $620 \mathrm{~nm}$ & $\mathrm{Co}_{3} \mathrm{O}_{4}$ thin film electrode & $10^{-6}-10^{-2}$ & & $\mathrm{pH} 9.3 ; 90 \%$ response time after $50 \mathrm{~s}$ at RT \\
\hline [20] & Transmittance at $530 \mathrm{~nm}$ & $\mathrm{NiO}$ thin film electrode & $10^{-5}-10^{-2}$ & & $\mathrm{pH} 9.3 ; 90 \%$ response time after $40 \mathrm{~s}$ at $\mathrm{RT}$ \\
\hline [21] & Spectrophotometry at $500 \mathrm{~nm}$ & $\mathrm{MnCo}_{2} \mathrm{O}_{4}$ thin film electrode & $10^{-6}-10^{-2}$ & & $\mathrm{pH} 9.7 ; 90 \%$ response time after $40 \mathrm{~s}$ at $\mathrm{RT}$ \\
\hline This method & Luminescence at $616 \mathrm{~nm}$ & EuTc complex & $5 \times 10^{-6}-7.5 \times 10^{-4}$ & $5 \times 10^{-6}$ & $\begin{array}{l}\text { Luminescence quenching; } \mathrm{pH} 7 ; 210 \mathrm{~nm} \text { Stokes' shift; } 20 \mathrm{~min} \\
\text { incubation time, microtiter plate assay possible }\end{array}$ \\
\hline
\end{tabular}


determination with Alizarin Red sulfonate [17] is performed at $\mathrm{pH}$ 6.6, and the three-enzyme method using Amplex Red [23] at $\mathrm{pH} 7.4$.

The EuTc assay has a comparatively wide linear detection range using no lagtime and a short integration time or significantly enhanced sensitivity with $60 \mu$ s lagtime in the $3-10 \mu \mathrm{M}$ concentration range.

\section{Conclusion}

A new method for simple and rapid determination of phosphate in microplate format has been developed employing the EuTc probe. It is particularly useful for phosphate detection in biological and biochemical systems because it works best at neutral $\mathrm{pH}$ and the linear range of the calibration plot is in the $\mu \mathrm{M}$-range. Future work will focus on monitoring enzymatic action like phosphatase activity with this lanthanide-based fluorescent assay.

\section{Acknowledgement}

MT thanks the Deutsche Forschungsgemeinschaft (DFG) for financial support within the graduate college "Sensory Photoreceptors in Natural and Artificial Systems".

\section{References}

[1] Z. Chen, P. Grierson, M.A. Adams, Anal. Chim. Acta 363 (1998) 191.

[2] R. De Marco, C. Phan, Talanta 60 (2003) 1215-1221.

[3] M.C.T. Diniz, O.F. Filho, E.V. de Aquino, J.J.R. Rohwedder, Talanta 62 (2004) 469.

[4] A. Greenberg (Ed.), Standard Methods for the Examination of Water and Wastewater, 18th ed., APHA AWWA NPCF, Washington, 1992, p. 446.

[5] H. Tiessen (Ed.), Phosphorus in the Global Environment: Transfers, Cycles, and Management, Wiley, Chichester, 1995, p. 462.
[6] D.B. Enders, R.K. Rude, Mineral and Bone Metabolism, in: C.A. Burtis, E.R. Ashwood (Eds.), Tietz Textbook of Clinical Chemistry, W.B. Saunders, Philadelphia, PA, 1999, pp. 1406-1408, 1439-1440.

[7] L.C. Thomas, G.J. Chamberlin (Eds.), Colorimetric Chemical Analytical Methods, Wiley and Sons, Chichester, 1980, p. 308.

[8] C.Z. Katasaounos, D.L. Giokas, A.G. Vlessidis, E.K. Paleologos, M.I. Karayannis, Sci. Total Environ. 305 (2003) 157.

[9] J.F. Van Staden, R.E. Taljaard, Microchim. Acta 128 (1998) 223.

[10] L. Drummond, W. Maher, Anal. Chim. Acta 302 (1995) 69-74.

[11] A.Y. El-Sayed, Y.Z. Hussein, M.A. Mohammed, Analyst 126 (2001) 1810.

[12] M. Oshima, N. Goto, J.P. Susanto, S. Motomizu, Analyst 121 (1996) 1085.

[13] W. Fusheng, W. Zhongxiang, T. Enjiang, Anal. Lett. 22 (1989) 3081

[14] N. Ichinose, M. Mitsui, Fresenius Z. Anal. Chem. 330 (1988) 634.

[15] J. Holzbecher, D.E. Ryan, Anal. Chim. Acta 64 (1973) 147.

[16] D.B. Land, S.M. Edmonds, Microchim. Acta 6 (1966) 1013.

[17] A.M. Abdallah, M.E. Khalifa, M.A. Akl, Anal. Chim. Acta 251 (1991) 207.

[18] S.L. Tobey, E.V. Anslyn, Org. Lett. 5 (2003) 2029.

[19] Y. Shimizu, Y. Furuta, Solid State Ionics 113-115 (1998) 241.

[20] Y. Shimizu, T. Yamashita, S. Takase, Jpn. J. Appl. Phys. 39 (2000) 384.

[21] Y. Shimizu, M. Shiotsuka, Jpn. J. Appl. Phys. 41 (2002) 6243.

[22] S. Cosnier, C. Gondran, J.-C. Watelet, W. DeGiovanni, R.P.M. Furriel, F.A. Leone, Anal. Chem. 70 (1998) 3952.

[23] M.V. Vazquez, B. Rodriguez, C. Zapatero, D.G. Tew, Anal. Biochem. 320 (2003) 292.

[24] V.-M. Mukkala, M. Mikola, I. Hemmilä, Anal. Biochem. 176 (1989) 319.

[25] G. Mathis, Clin. Chem. 39 (1993) 1953.

[26] E.P. Diamandis, T.K. Christopoulos, Anal. Chem. 62 (1990) 1149A.

[27] O.S. Wolfbeis, A. Dürkop, M. Wu, Z. Lin, Angew. Chem. Int. Ed. 41 (2002) 4495.

[28] W. Lei, A. Dürkop, Z. Lin, M. Wu, O.S. Wolfbeis, Microchim. Acta 143 (2003) 269.

[29] O.S. Wolfbeis, M. Schäferling, A. Dürkop, Microchim. Acta 143 (2003) 221.

[30] L.M. Hirschy, T.F. Van Geel, J.D. Winefordner, R.N. Kelly, S.G. Schulman, Anal. Chim. Acta 166 (1984) 207.

[31] K. Štamberg, P. Beneš, J. Mizera, J. Dolansky, D. Vopalka, K. Chalupska, J. Radioanal. Nucl. Chem. 258 (2003) 329. 